\title{
The level of visitors' satisfaction in relation to their expectation in Gashaka-Gumti national park, Nigeria
}

\begin{abstract}
The study was conducted to determine level of visitors' satisfaction in relation to their expectation as it relates to different products and services consumed within Gashaka-Gumti National Park, Nigeria. Fifty nine (59) questionnaires were administered to visitors within the study period. The questionnaire elicits information on their personal data, motivation, expectation and satisfaction. The results showed that $80 \%$ of the visitors fall between the ages of $20-29$ years, $89.2 \%$ is singles, while $86.5 \%$ had tertiary education. Sighting of wildlife bird (4.52) had the highest mean value of expectation, followed by ability to enjoy nature in the park (4.49) while limited number of visitors (3.63) had the lowest mean value. Limited number of visitors admitted to the park (4.77) had the highest level of satisfaction, while accessible features for people with disabilities had the lowest mean value. The critical mean value for satisfaction is (3.72), while the perception of staff on visitors' level of satisfaction indicated that $58.3 \%$ opined that the visitors were very satisfied, while none $(0 \%)$ indicated that the visitors are not satisfied at all (Not at all satisfied) in order to enhance future development of the Park. Regular feedback should be gotten in form of questionnaire or interaction with the visitors to evaluate their opinion about Gashaka-Gumti National Park.
\end{abstract}

Keywords: expectation, satisfaction, national park, visitors, environment
Volume 4 Issue 2 - 2019

\author{
AKINOLA Olufunlola Odunayo \\ Federal College of Forestry, Nigeria
}

Correspondence: AKINOLA Olufunlola Odunayo, Federa College of Forestry, Jericho, Ibadan, Forestry Research Institute of Nigeria (FRIN), Nigeria, Email funmod.akl@gmail.com

Received: April 09, 2019 | Published: April 24, 2019

\section{Introduction}

Ecotourism is a form of tourism involving visiting fragile, pristine and relatively undisturbed natural areas intended as a low impact and often small scale alternative to standard commercial tourism. It is about creating and satisfying a hunger for nature, about exploiting tourism's potential for conservation and development and averting its negative impact on ecology, culture and aesthetics. Wildlifebased tourism can be regarded as a type of ecotourism, and is often perceived to be effective in promoting conservation of important species and habitats in developing countries. ${ }^{1}$ Recent studies across the world has revealed that the number of tourists seeking interactions with wildlife in their natural environment is increasing, ${ }^{2,3}$ and has led to high revenues generated from wildlife tourism.

The International Council of Monument and Sites, ${ }^{4}$ stated that "for a visitor to have satisfaction during a visit, the experience must be worthwhile, satisfying and enjoyable. It should present high quality information to optimize the visitors' understanding of the site and need for protection, provide appropriate facilities for comfort, safety and wellbeing of the visitors, must ensure that tourism promotion create a realistic expectations and also minimizes fluctuations in visitors' arrivals and even the flow as much as possible". Satisfaction is a vital element in the survival of any tourism attraction/facility or destination, ${ }^{5}$ as it plays a significant role in the tourist deciding whether to recommend a place to others or to revisit the sites Kozak \& Rimmington ${ }^{6}$ It is common knowledge that if consumers are not happy with the performance of one or more components of the destination, it will likely affect how their overall satisfaction will be. ${ }^{7}$ Since it is an established fact that visitors' inflow is a function of their satisfaction it is therefore expedient to study the level of visitors' satisfaction in relation to their expectation in Gashaka-Gumti National Park.

\section{Materials and methods}

The study area: Geographically, Gashaka-Gumti National Park lies between 6055' $\mathrm{N}$ and 8005' $\mathrm{N}$ and between 11o11'E and 12013' E, it falls between Adamawa and Taraba States. It covers an approximate area of 6,731 square kilometers. The Gotel Mountains in the Gashaaka sector of the Park are located to the east of Sabere, these include Chappel Waddi, Chappel Delam and the mountain of Gangiravel, which is the highest mountain in Nigeria $(2,419 \mathrm{~m})$. Many areas of the Park are more accessible from Cameroon than they are from Nigeria. Greater part of the northern part of the Park is savannah grassland while sector of the Park has a rugged terrain characterized by very mountainous steep slope, as well as deep valley and gorges. The early period of dry season is characterized by the dry sand laden harmattan wind blowing from the North-east to Sahara desert. The local climate is influenced by topography, with different regions of the Park receiving different amount of rainfall, depending on location and altitude. The wettest areas of the Park are located in the mountain ranges of the southern sector of the Park. There is a wide range in humidity from $26-78 \%$. The annual temperature range is approximately $21^{\circ} \mathrm{C}-32^{\circ} \mathrm{C}$, while the mean annual rainfall is $1897 \mathrm{~mm}$. The Park is blessed with abundance of important wildlife species and this accord the Park the honour of having an ecosystem with high biodiversity. Giant eland (Taurotragus derbianus) and red-fronted gazelle (Eudorcas rufifrons), chimpanzee (Pan troglodytes), African golden cat (Caracal aurata), giant forest hog (Hylochoerus meinertzhageni) are part of animal species present within the park. Rare species such as mountain reedbuck (Redunca fulvorufula), roan antelope (Hippotragus equines), hippopotamus (Hippopotamus amphibius), wild dog (Lycaon pictus) are also available within the park. ${ }^{8}$ The Park has been recognized as Important Bird Area (IBA) by Nigeria Conservation Foundation .The Park also contains some historic sites one of which is the pre 1918 German fort and garrison top of Gashaka Hill once used as a watch tower by the German military expenditure (Figure 1). Source of data and sampling technique: The target respondents were the tourists that visited Gashaka Gumti National Park. The average annual tourist visitation to Gashaka Gumti National Park for a period of five years inform the choice of 56 numbers of questionnaires that were administered to tourists that were present at the study site as presented in Figure 2. The questionnaire covers different area such as demographic structure of 
the respondent, their expectation and level of satisfaction on different products and services from the Park (Figure 2).

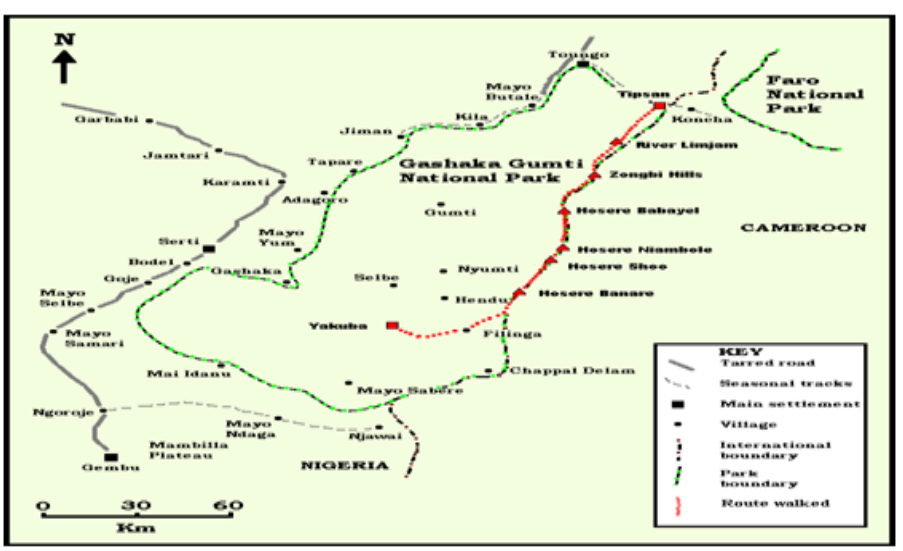

Figure I Map of Gashaka Gumti National Park, Taraba State, Nigeria.

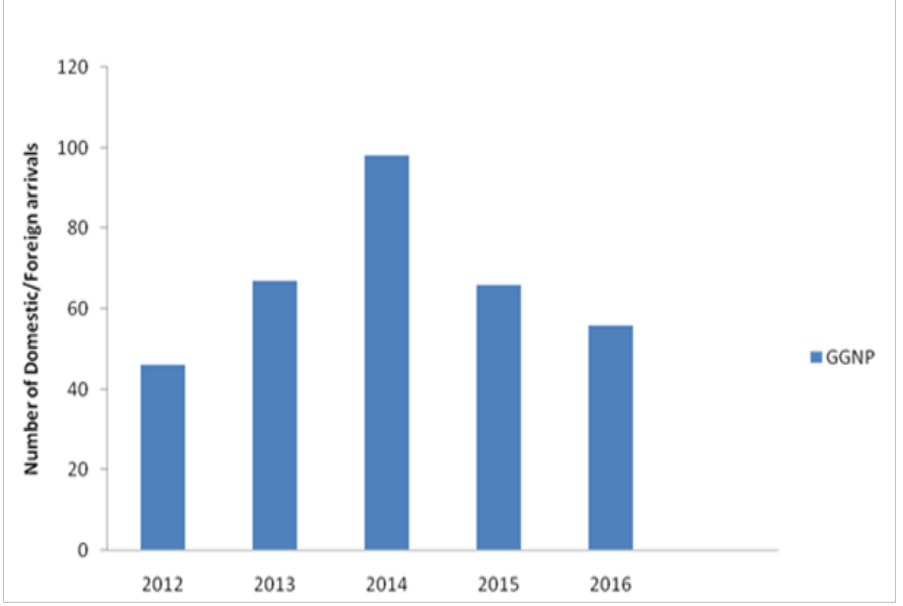

Figure 2 Annual tourist visitations of Gashaka Gumti National Park.

\section{Data Analysis}

Tourists' expectation and satisfaction was analyzed using five point Likert scale, the response of an item for each variable were multiplied by the weight attached to obtain response scores. The mean response values are as follows (Table 1):

$$
=\sum \frac{x f}{n}
$$

Where $\mathrm{X}=$ mean;

$\sum=$ summation

$\mathrm{X}=$ normal value of response;

$\mathrm{f}=$ frequency of response under each mode;

$\mathrm{n}=$ number of respondents on items.

The cut-off point was determined by finding the mean of the nominal value assigned to the options using the formula

$$
\frac{1+2+3+4+5}{5}=\frac{15}{5}=3.0
$$

Table I Tourists' expectation and satisfaction was analyzed using five point Likert scale, the response of an item for each variable were multiplied by the weight attached to obtain response scores

\begin{tabular}{ll}
\hline Expectation & Satisfaction \\
\hline Not at all important $=I$ & Not at all satisfactory $=1$ \\
Not very important $=2$ & Not very important $=2$ \\
Somewhat important $=3$ & Somewhat satisfactory $=3$ \\
Very important 4 & Very satisfactory $=4$ \\
Extremely important $=5$ & Extremely satisfactory $=5$ \\
\hline
\end{tabular}

To make inferential statements, the mean score was compared with the critical mean 3.0, if the calculated mean is equal to or greater than the standard critical value for expectation, it means that the tourists expectation was met, if it is lower, it shows that the tourists expectation was not met. Also for satisfaction if the calculated mean is equal to or greater than the standard critical value for expectation, it means that the tourists were satisfied, on the contrary, if it is lower than the critical value, it means that the visitors were not satisfied. An expectation-satisfaction matrix was developed, based upon the grand mean; tourists' expectation was divided into two groups, namely low-and high-expectations. Similarly, satisfaction level of tourists was grouped as low- and high-Satisfaction levels. In this context, there were four different quadrants in the matrix. The quadrant " $\mathrm{A}$ " group high-expectation and high-satisfaction, the quadrant " $\mathrm{B}$ " is low expectation and low-satisfaction, quadrant " $\mathrm{D}$ " is high-expectation and low-satisfaction, and the quadrant " $\mathrm{C}$ " indicates low-expectation and high-satisfaction. Destination attributes were distributed in the matrix according to their grand means.

\section{Statistical analysis}

The data was analyzed using statistical tools such as descriptive statistics, bar chart with the aid of $\mathrm{R}$ programming.

\section{Results and discussion}

Demographic structure of the respondents indicates that tourists to Ghasaka Gumti National Parks are mostly males as the gender percentage of male is $78.4 \%$. This is contrary to Philipo, ${ }^{9}$ where approximately $52 \%$ of visitors to Serengeti National Park were females and $48 \%$ of them were males. However Clarke \& Critcher, ${ }^{10}$ argue on the context of leisure participation that women have less time than men, undertake fewer leisure activities and spend a higher proportion of their time in and around the family. Gladwell \& Bedini, ${ }^{11}$ affirms that women's caring role do not relate to children alone as 7080 percent of those caring for elderly, relatives or partners are women this makes tourism to be an issue for most women. The age structure reveals that most visitors fall between the ages of 20-29years $(80 \%)$. This is in accordance with Jones ${ }^{12}$ which ascertain that travelling is one of the signs of adulthood in youths in which they show their freedom and their ability to move around. The age distribution has important implication to the future visitation of the park, as it implies the possibilities of reasonable age of return to the area.

Marital status indicates that the tourists are mostly singles (89.2\%), this affirms Thornton, where it was observed that children certainly have an effect in tourism behaviour as married couples give consideration to their children before embarking on any trip, especially overseas trips, thus making singles to be more mobile. Most tourists 
in the study Parks have high level of formal education as $86.5 \%$ of the tourists passed through tertiary institution, this is in accordance with, ${ }^{13}$ which affirms that higher educational level are strongly correlated with demand for outdoor recreation activities.

Figure 3 show the percentage distribution of visitors based on their motive and it was observed that the primary aim of $64 \%$ of the visitors is to learn about nature, while $10 \%$ of them were there in order to carry out research work (Table 2) (Figure 3). Products offered to visitors include Park viewing, Water recreation, Sport fishing, Tour to cultural sites/festival, Hunt with personal camera, Accommodation, Natural history museum and lake cruise. Facilities within the Park include Restaurant, Health care center (sick bay) and tour guide. There are no facilities for people with physical challenge both does the Park has Tour Guides but has efficient Rangers and other Staff who are highly proficient to fill in the gap. The Park also has Nurses who can take care of any emergency within the Park. Survey of accommodation facilities within the Park revealed that there are Executive Suite (2), Executive Suite (7), V I P Lodge (4) and Double Chalet (6) which is adequate for the present influx of visitors. There are no adequate vehicles to convey visitors within the Park as there are only Toyota Hilux (6), Land Cruiser (2), Toyota Coastal Bus (1), Peugeot 504 station wagon (2), Land Rover (5) and Tractor (2) which is meant to cater for both Staff and Visitors (Table 3).

Table 2 Demographic structure of Tourists in the Study Parks

\begin{tabular}{lc}
\hline Gender & GGNP \\
\hline Male & 78.4 \\
Female & 21.6 \\
Age & \\
$<20$ & 2.9 \\
$20-29$ & 80 \\
$30-39$ & 14.3 \\
$40-49$ & 2.9 \\
$>50$ & 0 \\
Marital Status \\
Single & 89.2 \\
Married & 10.8 \\
Divorced & 0 \\
Level of Education \\
Primary & 0 \\
Secondary & 13.5 \\
Tertiary & 86.5 \\
\hline
\end{tabular}

Visitor's satisfaction was related to their expectation. Table 2 shows that the expectation of tourists in regards to various attributes, facilities, services and products in the Parks differs from one product to another as opined by Akin et al., ${ }^{14}$ that satisfaction is a function of expectations, as related to destination attributes. ${ }^{15}$ It revealed that sighting of wildlife birds (4.52) had the highest mean value of expectation, followed by ability to enjoy nature in the Park (4.49) while limited number of visitors (3.63) had the lowest mean value for expectation. Accessible features for people with disabilities had the lowest mean value for satisfaction in GGNP (1.86), limited number of visitors admitted to the Park at the same time had the highest level of satisfaction in (4.77) (Table 4).

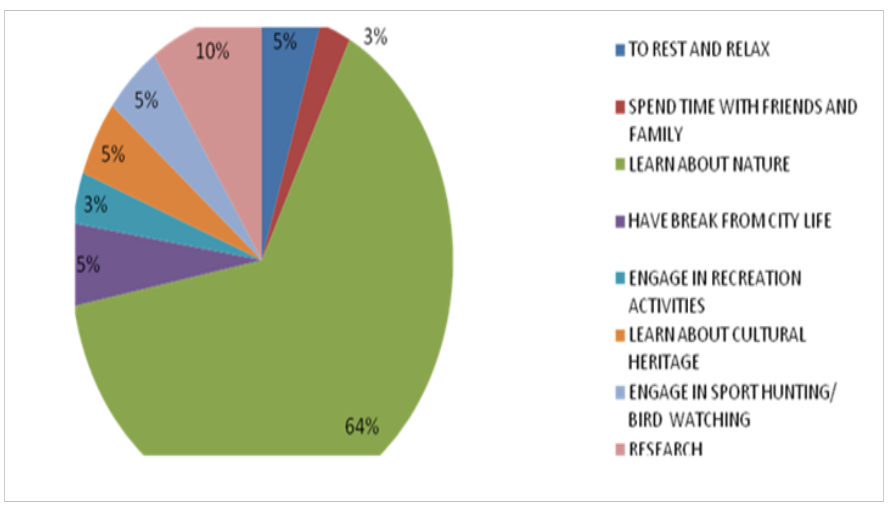

Figure 3 Percentage distribution of tourists to Gashaka Gumti National Park based on Motivation.

Table 3 Tourists' Expectation and satisfaction from the Study Parks

\begin{tabular}{|c|c|c|}
\hline Factors & $\begin{array}{l}\text { Expectation } \\
\text { Means } \pm \text { Std.D }\end{array}$ & $\begin{array}{l}\text { Satisfaction } \\
\text { Means } \pm \text { Std.D }\end{array}$ \\
\hline $\begin{array}{l}\text { Early access to pre-visit } \\
\text { information about the Park }\end{array}$ & $4.45 \pm 0.57$ & $3.8 I \pm 0.83$ \\
\hline $\begin{array}{l}\text { Useful directional road signs in } \\
\text { the Park }\end{array}$ & $3.84 \pm 0.86$ & $1.86 \pm 0.86$ \\
\hline $\begin{array}{l}\text { Access to friendly, responsive } \\
\text { Park staff }\end{array}$ & $4.0 I \pm 0.77$ & $2.44 \pm 0.65$ \\
\hline $\begin{array}{l}\text { Access to accommodation } \\
\text { facilities }\end{array}$ & $4.23 \pm 0.92$ & $3.02 \pm 0.98$ \\
\hline Access to toilet facilities & $3.68 \pm 0.90$ & $1.80 \pm 0.47$ \\
\hline Restaurant & $3.89 \pm 0.47$ & $2.62 \pm 0.84$ \\
\hline Well designed \& maintained roads & $4.2 I \pm 0.93$ & $3.4 I \pm 0.89$ \\
\hline $\begin{array}{l}\text { Well designed \& maintained } \\
\text { walking tracks/trail }\end{array}$ & $4.13 \pm 0.70$ & $3.23 \pm 0.87$ \\
\hline $\begin{array}{l}\text { Ability to enjoy nature in this } \\
\text { Park }\end{array}$ & $4.49 \pm 0.89$ & $3.44 \pm 0.57$ \\
\hline Sightings of native wildlife/birds & $4.62 \pm 0.57$ & $3.49 \pm 0.89$ \\
\hline $\begin{array}{l}\text { Access to water (e.g., lake, river, } \\
\text { ocean) }\end{array}$ & $3.66 \pm 0.80$ & $3.8 I \pm 0.88$ \\
\hline $\begin{array}{l}\text { Healthy water condition (e.g., } \\
\text { lake, river, ocean) }\end{array}$ & $4.01 \pm 0.92$ & $4.09 \pm 0.81$ \\
\hline $\begin{array}{l}\text { Availability of range of activities } \\
\text { (e.g., walking, picnicking, bird } \\
\text { watching) }\end{array}$ & $4.1 I \pm 0.70$ & $3.25 \pm 0.95$ \\
\hline $\begin{array}{l}\text { Access to interesting guided } \\
\text { walks/talks by rangers/others }\end{array}$ & $4.4 I \pm 0.54$ & $2.75 \pm 0.97$ \\
\hline $\begin{array}{l}\text { Access to interesting information } \\
\text { on culture (e.g., Aboriginal, non- } \\
\text { aboriginal, heritage) }\end{array}$ & $3.92 \pm 0.54$ & $3.25 \pm 0.94$ \\
\hline $\begin{array}{l}\text { Availability of useful visitor } \\
\text { guides/maps in the Park }\end{array}$ & $4.21 \pm 0.83$ & $3.54 \pm 0.57$ \\
\hline
\end{tabular}


Table Continued

\begin{tabular}{lll}
\hline Factors & $\begin{array}{l}\text { Expectation } \\
\text { Means } \pm \text { Std.D }\end{array}$ & $\begin{array}{l}\text { Satisfaction } \\
\text { Means } \pm \text { Std.D }\end{array}$ \\
\hline $\begin{array}{l}\text { Availability of useful information } \\
\text { on plants \& animals in the Park }\end{array}$ & $4.45 \pm 0.87$ & $3.04 \pm 0.8 \mathrm{I}$ \\
$\begin{array}{l}\text { Clear information about visitor } \\
\text { safety }\end{array}$ & $3.83 \pm 0.83$ & $2.53 \pm 0.99$ \\
$\begin{array}{l}\text { Sustained security in the Park } \\
\begin{array}{l}\text { Limited number of visitors } \\
\text { admitted into the Park at the } \\
\text { same time. }\end{array}\end{array}$ & $4.41 \pm 0.54$ & $2.27 \pm 0.95$ \\
$\begin{array}{l}\text { Accessible features for people } \\
\text { with disabilities) }\end{array}$ & $3.63 \pm 0.73$ & $4.77 \pm 0.95$ \\
$\begin{array}{l}\text { Hospitality exhibited by the Park } \\
\text { staff }\end{array}$ & $4.69 \pm 0.57$ & $1.53 \pm 0.87$ \\
$\begin{array}{l}\text { Availability of customer care } \\
\text { services }\end{array}$ & $4.73 \pm 0.47$ & $2.01 \pm 0.54$ \\
$\begin{array}{l}\text { Availability of sport facilities } \\
\text { Pan }\end{array}$ & $3.69 \pm 0.73$ & $2.76 \pm 0.87$ \\
\hline
\end{tabular}

Table 4 Perceptions of Park Staff on the Level of Tourists' Satisfaction

\begin{tabular}{ll}
\hline Level of visitors satisfaction & GGNP (\%) \\
\hline NAS & 0 \\
NVS & 14.6 \\
SS & 12.5 \\
VS & 58.3 \\
ES & 14.6 \\
Mean & $3.72 *$ \\
SD & 0.89 \\
\hline
\end{tabular}

Where:

NAS $=$ Not at all satisfactory $=1$

NVS $=$ Not very important $=2$

SS $=$ Somewhat satisfactory $=3$

$\mathrm{VS}=$ Very satisfactory $=4$

$\mathrm{ES}=$ Extremely satisfactory $=5$

Generally, attributes that fall within quadrant "A" are attributes that tourists had high expectation before their visit to the Park and such expectations are met with high satisfaction, attributes include; Sightings of native wildlife/bird, ability to enjoy nature in this Park; early access to pre-visit information about the Park; availability of useful information on plants \& animals; access to interesting guided walks/talks by rangers: hospitality exhibited by the Park staff; access to accommodation facilities; availability of useful visitor guides/maps; healthy water condition; access to friendly, responsive Park staff; well designed and maintained road. Attributes in quadrant "B" are those with low expectation before the visit, with equal low satisfaction after the visit. Such attributes include access to interesting information on culture; Restaurant; Useful directional road signs in the Park; Clear information about visitor safety; Availability of sport facilities; Access to toilet facilities. Those attributes such as access to water; Limited number of visitors admitted into the Park at the same time are in quadrant " $C$ " where low expectations are met with high satisfaction while Sustained security in the Park; Availability of customer care services; Accessible feature a for people with disabilities; Well designed \& maintained walking tracks/trail; Availability of range of activities those in quadrant "D" with low expectation before the visit which was equally met with low satisfaction after the visit as presented in Figure 4. The major aim of most of the tourists is to know more about nature. This can be achieved by their ability to enjoy nature, sightings of native wildlife/birds, access to interesting guided walks/talks by ranger, availability of useful information on plants and animals. Considering tourists' level of satisfaction in relation to their purpose of visit within Expectation-Satisfaction Matrix, it was observed that all these attributes are within quadrant " $A$ " in GGNP. This means that the tourists have high level of expectations for all these attributes which are equally met with high level of satisfaction as revealed in Figure 4.

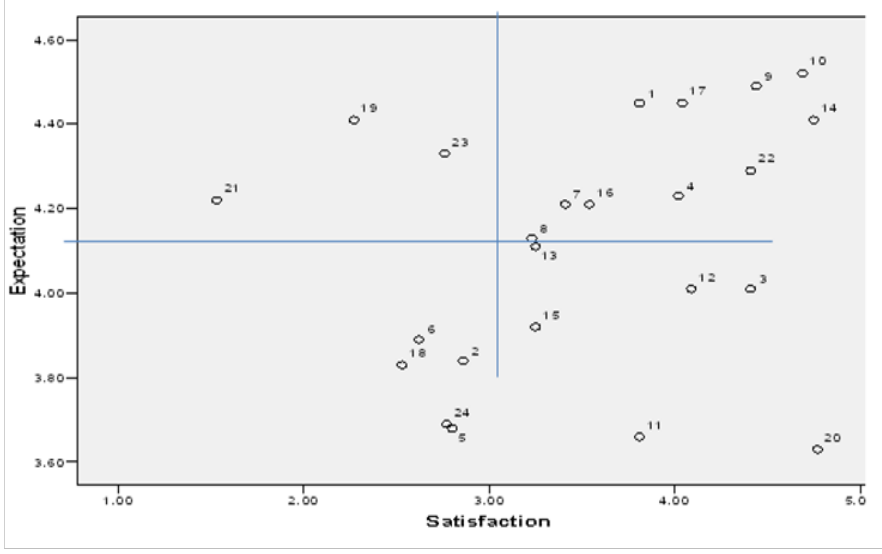

Figure 4 Expectation-Satisfaction Matrixes in GGNP.

\section{Conclusion}

Tourists to Gashaka-Gumti National Park are majorly males, singles with tertiary education. The present accommodation is adequate for the present volume of visit to the Park. The Park is blessed with Staff who are proficient to stand in as Tour Guides as there are no Tour Guides in the Park, thereby making the visit worthwhile for visitors. $68.3 \%$ of the visitors visited the Park because they want to enjoy nature. Sightings of native wildlife/bird, ability to enjoy nature in this Park; early access to pre-visit information about the Park; availability of useful information on plants \& animals; access to interesting guided walks/talks by rangers: hospitality exhibited by the Park staff; access to accommodation facilities were part of the attributes and products with high expectation that were equally met with high satisfaction by Visitors in order to enhance future development of the Park, regular feedback should be gotten in form of questionnaire or interaction with the visitors to evaluate their opinion about the Park. There is need to create more products such as walking safari, balloon safari and sundowner, in order to create more activities that will enable the visitors to have a longer stay with worthwhile experience during their stay.

\section{Acknowledgements}

None.

\section{Conflicts of interest}

The author declares that there are no conflicts of interest. 


\section{References}

1. Newsome D, Dowling R, Moore S. Wildlife Tourism. UK, Cleveton Channel View Publications; 2005. 320 p.

2. Meduna AJ, Amusa TO, Ogunjinmi AA, et al. Environmental Friendly Tourism in Nigeria: A Case Study of Nigerian National Park Service. Nigerian Journal of Forestry. 2005;35(1):36-43.

3. Lindsey PA, Alexander R, Mills MGL, et al. Wildlife viewing preferences of visitors to Protected Areas in South Africa: Implications for the role of ecotourism in conservation. Journal of Ecotourism. 2007;6(1):19-33.

4. ICOMOS. International Cultural Tourism Charter: Managing Tourism at laces of Heritage Significance. (Homepage of ICOMOS). 1999. 6 P.

5. Neal JD, Gursor D. Multifaceted analysis of tourism satisfaction. Journal of Travel/Research. 2008;47(1):53-62.

6. Kozak M, Rummington M. Tourists' Satisfaction with Mallorca, Spain as off-season holiday destination. Journal of Travel and Research. 2000:38(3);260-269.

7. Pizza A, Neumann, Yand Reichad A. Dimension of Tourists Satisfaction. Grand Annals of Tourism research. 1978;5(2):314-323.

8. Gunn C. Tourism Planning Basic concept, Cases. $3^{\text {rd }}$ edn. Washington DC: Taylor; 1994. 460 p.
9. Philipo N. Visitor's Experience on Tourism Services and Facilities in Serengetti National Park. An Attitudinal and Perception Assessment SENAPA. Austria: University of Klagenfurt; 2001. 72p.

10. Clarke J, Critcher C. The Devil makes Work. London: Basingstoke Macmillan; 1988. 220 p.

11. Gladwell, Bedini. In Search of Lost Leisure: The Impact of Care giving on Leisure Travel. Tourism Management. 2004;25(6):685-693.

12. Jones S. community-based ecotourism: the significance of social capital. Annals of tourism research. 2005;32(2):303-324.

13. Cole ND. Visitors use density and wilderness experience. A historic review of research. In: Warne $\mathrm{F}$, Cole W, editors. Visitor use density and wilderness experience: proceedings Missoula, USA: 2000. pp 11-20.

14. Akin, Ebru T, Rüya E. A Comparison of Tourist Expectations and Satisfaction: A Case Study from Antalya Region of Turkey. TURIZAM. 2010;14(2):66-77.

15. Dogan Gursoy, Ken W McCleary, Lawrence R Lepsito. Propensity to complain effects of personality and behavior factors. Journal of Hospitality and Research. 2007;31(3):328-386. 